\title{
Right Brain: A state of emotional aphasia
}

Essam Al-Sibahee, MD

Neurology ${ }^{\circledR}$ 2019;93:e210-e211. doi:10.1212/WNL.0000000000007757
Correspondence

Dr. Al-Sibahee

essam.munir95@gmail.com

We learned in medical school how to manage different conditions and communicate with patients in the most empathic way possible. In being empathetic, we also recognized the need to balance honesty and empathy. But, deep down in our hearts, we knew that this balance would crumble someday.

It crumbled for me with A.M., an 11-month-old boy with hydrocephalus who was admitted to the pediatric neurology ward due to fevers. A.M. stayed in a room with 5 other ill children. While A.M. was lying in bed, his eyes moved continuously, his cries were muffled, and his limbs were hypotonic. It was difficult for his mother to hold him, as his head was so big. Macrocephaly, dark eyes, hypotonic limbs, and pale skin; these features made him alien to others in the hospital.

Parents stayed with their children, making the rooms more crowded. Overcrowding is a problem in most of the hospitals in Iraq. Thus, no conversation is held in private and doctors struggle to break bad news or discuss sensitive issues with patients or their guardians. All of the other parents, then, noticed A.M.'s condition. They turned their heads and mumbled whenever we approached him. Old women recited religious verses praying for him to get better and attempting to ward off such an affliction from their loved ones.

In crowded hospitals, senior doctors may not have enough time to answer patients' questions or concerns. As a result, this duty is passed to junior doctors, who may lack the experience to communicate skillfully. I was no exception, especially in the case of A.M.

I asked for permission to examine A.M. and his mother assented. I finished the examination and looked at the CT scan, and strikingly, I could not see the cerebrum. There was only brainstem and a rim of brain tissue anteriorly. A.M. had hydranencephaly, a condition characterized by absence of cerebral hemispheres.

Babies with hydranencephaly are expected to die within the first year of life and A.M. was approaching this age. ${ }^{1} \mathrm{I}$ asked his mother whether she knew anything about his condition, and she said yes. Twenty-six weeks into being pregnant with him, she knew that she would have a baby with an abnormality of the brain. She knew the course would be unpredictable and extra effort would be needed to care for him, as well as his 5 older siblings. She looked tired and helpless; she was routinely in hospital due to A.M.'s recurrent infections. She hoped her child would get a VP shunt, as his condition was deteriorating, but the recurrent infections delayed this procedure. We discussed the management and duration of stay in hospital as well as the procedure. I felt confident about my ability to answer her questions until her last inquiry. She asked with a very sad tone: "Doctor, can he see me?"

A mother filled with love asking for solace. She wanted him to know the person who fed, carried, and cleaned him. My brain was flipping through the pages I read during medical school looking for an empathic answer. Should I be honest and say "no," or should I say "I did not learn this in medical school"? She noticed the confusion on my face and knew the answer without me saying it. After all, she told me that he did not follow her with his eyes, but he got calmer whenever she touched or talked to him. But she wanted me to say something. I looked to the floor, avoiding her hopeful eyes; then, I held the torch close to his eyes, avoiding the question, and asking her to 
look at his eyes and see if they reacted to the torch. She did not ask whether reactivity means seeing or not, but I felt that she knew the answer. Reactivity is not the same as seeing.

After this encounter, I wondered how we can discuss prognosis and the facts of illness without making patients or parents lose hope. With A.M., there was no occipital cortex and it was clear to us that he could not see. I did not have the courage to tell her the truth, but both of us knew it.

Every doctor will experience a state of emotional aphasia when the facts are clear, but one fears the consequences of revealing them. A compromise is possible between the facts and patient's comfort if we pay more attention to the clues the patients are giving us. While we are being trained, we must pay attention to the wisdom in diagnosing and treating conditions as well as the skill of balancing empathy and honesty. And as with aphasia, intensive training is needed to find the words to express the facts while caring for the patient's emotions.
A.M and his mother discontinued treatment and left the hospital. But they left me with a question: when will I be cured of emotional aphasia?

\section{Acknowledgment}

The author thanks Dr. Aseel Q. Hadi, Baghdad Medical School, for general advice; Dr. Faisal R. Habib, Baghdad Medical School, for proofreading the manuscript; and Sadeer Q. Hadi, Al-Mustansiriyah University Translation Department, for proofreading the manuscript.

\section{Study funding}

No targeted funding reported.

\section{Disclosure}

E. Al-Sibahee reports no disclosures relevant to the manuscript. Go to Neurology.org/N for full disclosures.

\section{Reference}

1. National Institute of Neurological Disorders and Stroke. Hydranencephaly information page. Available at: ninds.nih.gov/Disorders/All-Disorders/Hydranencephaly-Information-Page. Accessed October 20, 2018. 


\section{Neurology}

\section{Right Brain: A state of emotional aphasia}

Essam Al-Sibahee

Neurology 2019;93;e210-e211

DOI 10.1212/WNL.0000000000007757

\section{This information is current as of July 8, 2019}

\section{Updated Information \&} Services

\section{Subspecialty Collections}

Permissions \& Licensing

\section{Reprints}

including high resolution figures, can be found at: http://n.neurology.org/content/93/2/e210.full

This article, along with others on similar topics, appears in the following collection(s):

Training-international

http://n.neurology.org/cgi/collection/training_international

Information about reproducing this article in parts (figures,tables) or in its entirety can be found online at:

http://www.neurology.org/about/about_the_journal\#permissions

Information about ordering reprints can be found online:

http://n.neurology.org/subscribers/advertise

Neurology ${ }^{\circledR}$ is the official journal of the American Academy of Neurology. Published continuously since 1951, it is now a weekly with 48 issues per year. Copyright @ 2019 American Academy of Neurology. All rights reserved. Print ISSN: 0028-3878. Online ISSN: 1526-632X.

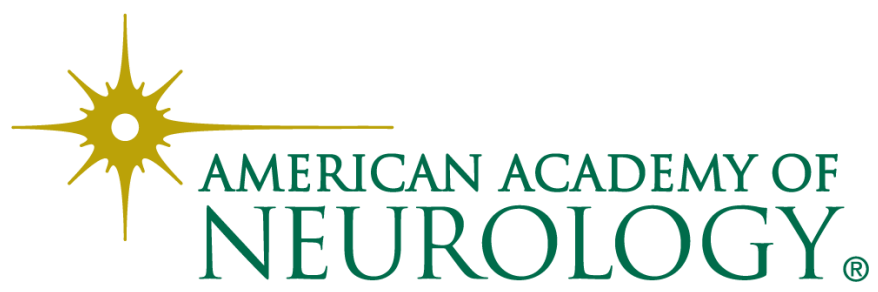

